\title{
Profil Kualitas Air Pada Budidaya Udang Vaname (Litopenaeus vannamei) Sistem Bioflok Dengan Sumber Karbohidrat Gula Aren
}

Yulianty Adipu*

Program Studi perikanan dan ilmu kelautan, Fakultas Pertanian, Universitas Gorontalo

\begin{tabular}{ll}
\hline K A T A K U N C I & A B S T R A K \\
\cline { 2 - 3 } $\begin{array}{l}\text { Kualitas Air } \\
\text { Gula Aren }\end{array}$ & $\begin{array}{l}\text { Pengelolaan kualitas air apabila dikaitkan dengan kegiatan Budidaya } \\
\text { tentunya menjadi faktor yang sangat perlu mendapatkan perhatian. Media }\end{array}$ \\
budang Vaname & $\begin{array}{l}\text { vandaya dalam hal kualitas air sangat mempengaruhi produktifitas udang } \\
\text { dalam budidaya udang sistem bioflok menggunakan gula aren sebagai }\end{array}$ \\
& sumber karbohidrat. Penelitian ini menggunakan rancangan acak lengkap \\
& dengan 3 perlakuan dan 3 kali ulangan. Perlakuan yang digunakan yaitu \\
& kontrol A (Tanpa campuran Fermentasi), Fermentasi B (campuran tepung \\
ikan dan Gula aren), Fermentasi C (hanya menggunakan Gula aren). & Parameter pengamatan terdiri dari 8 parameter kualitas air yaitu suhu, \\
& Do, pH, salinitas, nitrit. Nitrat, amoniak dan Total Suspended Solid. Hasil \\
penelitian menunjukkan bahwa peran bioflok menggunakan sumber \\
karbohidrat memberikan perubahan pada beberapa parameter kualitas \\
menjadi lebih baik, dengan adanya fermentasi gula aren yang \\
menghasilkan bakteri asam laktat juga berperan produktifitas udang \\
vaname.
\end{tabular}

K E Y W O R D S

Water Quality

Biofloc

Palm Sugar

Shrimp Vaname

\begin{abstract}
A B S T R A C T
Water quality management when associated with Aquaculture activities is certainly a factor that needs attention. Media culture in terms of water quality greatly affects the productivity of vaname shrimp. The purpose of this study is to find out the picture of water quality in the biofloc shrimp culture using palm sugar as a source of carbohydrates. This study used a completely randomized design with 3 treatments and 3 replications. The treatments used controlled A (without a mixture of fermentation), fermentation B (a mixture of fish meal and palm sugar), fermentation C (only using palm sugar). Observation parameters consisted of 8 parameters of water quality namely temperature, DO, pH, salinity, nitrite. Nitrate, Ammonia and Total Suspended Solid. The results showed that the role of biofloc using carbohydrate sources gave changes to several quality parameters for the better, with the presence of palm sugar fermentation which produced lactic acid bacteria also played a role in vaname shrimp productivity..
\end{abstract}

\section{Pendahuluan}

Upaya untuk mengembangkan perikanan budidaya sampai saat ini terus dilakukan terutama pada sistem budidaya intensif, berbagai kendala dihadapi seperti buangan limbah akuakultur, penggunaan pakan buatan yang menggunakan bahan pakan ikan sebagai campurannya. Udang vaname merupakan jenis udang yang dikenal memiliki beberapa kelebihan diantaranya tahan penyakit, dapat dibudidayakan pada tebar tinggi, serta tingkat produktivitasnya tinggi. Pada proses budidaya kegiatan pemberian pakan merupakan kebutuhan pokok dalam usaha budidaya. Umumnya

*Corresponding author: Program Studi perikanan dan ilmu kelautan, Fakultas Pertanian, Universitas Gorontalo;

Email address: yuliantyadipu@rocketmail.com

Published by FMIPA UNSRAT (2019) 
organisme akuatik membutuhkan protein yang cukup tinggi dalam pakannya, namun demikian organisme akuatik hanya dapat meretensi protein sekitar 20 - 25\% dan selebihnya akan terakumulasi dalam air (Stickney, 2005).

Teknologi bioflok menjadi salah satu teknologi terbaru yang terbaru yang diterapkan dalam kegiatan budidaya yang mengatasi masalah kualitas air dalam kegiatan budidaya. Menurut Aiyushirota (2009), .bioflok atau activated sludge (lumpur aktif) yang diadopsi dari proses pengolahan biologis air limbah dengan memanfaatkan bakteri bacillus untuk pembentukan flok. Berdasarkan penelitian terdahulu menunjukkan bahwa aplikasi teknologi probiotik berperan dalam perbaikan kualitas air, peningkatan biosekuriti dan peningkatan produktivitas (Rachmawati, 2015). Pada sistem konvensional pengolahan air budidaya dilakukan dengan cara pergantian air, sementara pada sistem bioflok pergantian air tidak dilakukan secara keselurihan tetapi hanya dilakukan penambahan air apabila terjadi pengupan.

Penambahan sumber karbohidrat pada sistem bioflok dimaksudkan untuk meningkatkan rasio $\mathrm{C} / \mathrm{N}$ dan merangsang pertumbuhan bakteri heterotrof yang dapat mengubah nitrogen anorganik menjadi biomassa bakteri (Crab et al., 2007). Pada penelitian ini menggunakan sumber karbohidrat alami berupa gula aren yang dianggap memiliki manfaat sama dengan molase pada umumnya digunakan. Penggunaan sistem bioflok selain diterapkan pada ikan lele pada umumnya juga diterapkan pada udang vaname. Adapun tujuan dari penelitian ini yaitu mengetahui gambaran kualitas air dalam budidaya udang sistem bioflok menggunakan gula aren sebagai sumber karbohidrat.

\section{Material dan Metode}

Hewan uji yang dilakukan dalam penelitian ini benih udang berukuran rata - rata 0,01 - 0,010 gr (Post Larva 8) dengan kepadatan 120 ekor/akuarium menggunakan 12 buah akuarium berkapasitas 60 liter air. Pemberian pakan dilakukan sebanyak 3 kali sehari yaitu pada pukul 07 : 00, 11:00 dan 16:00 sampai kenyang sebanyak $5 \%$ dari bobot tubuh. Persiapan bioflok dilakukan dengan melakukan fermentasi pada bahan - bahan yang akan digunakan yang membedakan dari setiap fermentasi adalah sumber karbohidrat dan untuk bahan campuran lainnya tetap sama. Adapun bahan - bahan yang akan digunakan dalam pembuatan fermentasi yaitu dedak halus $450 \mathrm{gr}$, ragi roti $15 \mathrm{gr}$, probiotik (Bacillus sp) $15 \mathrm{gr}$ dan sumber karbohidrat $450 \mathrm{gr}$ dan untuk kontrol tidak menggunakan tambahan sumber karbohidrat. Secara keseluruhan bahan bahan tersebut di larutkan dengan 6 liter air steril. Fermentasi ini di aerasi selama 7 hari sampai aroma yang dihasilkan netral tidak berbau, setelah 7 hari hasil fermentasi ditebar pada masing masing akuarium sebanyak 1 liter dan didiamkan selama 20 hari sambil terus di aerasi hal ini bertujuan untuk membentuk flok kemudian dilanjutkan dengan penebaran benih udang. parameter kualitas air yang di ukur yaitu Suhu, DO, $\mathrm{pH}$, salinitas, nitrit, nitrat, amonia, total suspendid solid. Hasil yang diperoleh dideskripsikan dengan menguraikan masing - masing parameter kualitas air yang diperoleh.

\section{Hasil dan Pembahasan \\ Selama masa pemeliharaan udang vaname menggunakan sistem bioflok tidak terdapat} perubahan suhu yang jauh, hal tersebut dikarenakan penempatan akuarium berada pada indoor sehingga tidak terpengaruh dari lingkungan luar. Parameter kualitas air yang diperoleh selama penelitian diuraikan pada tabel 1 .

Nilai suhu yang direkomendasikan untuk tumbuh pada udang vaname menurut Van Wyk et all (1999) adalah sekitar $28-32{ }^{\circ} \mathrm{C}$, sehingga nilai yang diperoleh selama penelitian yaitu 27 - $29{ }^{\circ} \mathrm{C}$ tersebut dianggap masih sesuai untuk pertumbuhan udang. Suhu berpengaruh langsung pada metabolisme udang, pada suhu tinggi metabolisme udang dipacu sedangkan pada suhu yang lebih rendah proses metabolism diperlambat. Secara tidak langsung suhu air yang tinggi menyebabkan oksigen dalam air menguap, akibatnya larva udang akan kekurangan oksigen. Peran suhu yang berhubungan erat dengan kandungan oksigen terlarut dalam air sehingga penting dalam hubungannya dengan cadangan polimer yang terdapat flok. Gula aren yang menjadi bahan untuk fermentasi mengandung asam laktat. Asam laktat dikaitkan dengan dengan media tumbuh bakteri asam laktat yang memerlukan suhu sekitar $29^{\circ} \mathrm{C}$ dalam proses fermentasinya (Subagiyo $d k k, 2015$ ). Bakteri asam laktat tentunya merupakan bakteri baik yang memperbaiki produktifitas pertumbuhan maupun kesehatan udang yang di budidaya.

Tabel 1. Hasil pengamatan kualitas air selama penelitian

\begin{tabular}{|c|c|c|c|c|c|}
\hline No & Parameter & $A$ & $B$ & C & Satuan \\
\hline 1 & Suhu & $27-31$ & $27-29$ & $27-29$ & $\left({ }^{\circ} \mathrm{C}\right)$ \\
\hline 2 & DO & $\begin{array}{l}6,0 \\
6,7\end{array}$ & $\begin{array}{r}5,6 \\
6,5\end{array}$ & $\begin{array}{r}5,9 \\
6,5\end{array}$ & $-\mathrm{Mg} / \mathrm{I}$ \\
\hline 3 & $\mathrm{pH}$ & $5-7$ & $6-7$ & $6-7$ & - \\
\hline 4 & Salinitas & $30-35$ & $30-35$ & $30-35$ & (ppt) \\
\hline 5 & Nitrit & $\begin{array}{l}0,00- \\
3,24\end{array}$ & $\begin{array}{l}0,00- \\
3,34\end{array}$ & $\begin{array}{l}0,00- \\
0,11\end{array}$ & $\mathrm{Mg} / \mathrm{I}$ \\
\hline 6 & Nitrat & $\begin{array}{l}9,03- \\
18,77\end{array}$ & $\begin{array}{c}3,53- \\
18,31\end{array}$ & $\begin{array}{r}7,42- \\
13,71\end{array}$ & $\mathrm{Mg} / \mathrm{I}$ \\
\hline 7 & Amonia & $\begin{array}{l}0,88 \\
2,42\end{array}$ & $-0,22-0,8$ & $\begin{array}{c}8.0,24- \\
2,63\end{array}$ & $\mathrm{Mg} / \mathrm{I}$ \\
\hline 8 & TSS & $85-295$ & $80-165$ & $595-195$ & $5 \mathrm{Mg} / \mathrm{I}$ \\
\hline
\end{tabular}

Selama kegiatan penelitian penggunaan aerasi di tempatkan pada setiap titik bagian akuarium untuk menghindari pengendapan flok, feses 
maupun sisa makan. Menurut Zulfami (2017), kisaran oksigen yang optimum yaitu > $4 \mathrm{Mg} / \mathrm{l}$. Proses respirasi pada udang serta fisiologi sel yang berperan dalam pembentukan energi selama proses metabolisme nutrien dalam pakan membutuhkan oksigen, rendahnya kandungan oksigen memnyebabkan kemampuan undang untuk metabolisme pakan menjadi terbatas sehingga menurunkan kemampuan untuk mengkonversi pakan. Kecenderungan menurunnya nilai kandungan oksigen pada perlakuan dibanding dengan kontrol karena adanya pemanfaatan oksigen oleh bakteri pada media pemeliharaan, sehingga nilai untuk kontrol yang tidak adanya bakteri didalamnya yang ikut mengkonsumsi bakteri sehingga nilai yang diberikan menjadi lebih tinggi.

Eliyani dkk (2015) menyatakan bakteri nitrifikasi membutuhkan $4.6 \mathrm{mg} / \mathrm{l}$ oksigen untuk dapat mengoksidasi $1 \mathrm{mg}$ amonia dan untuk dapat bekerja bakteri nitrifikasi membutuhkan DO minimal $2 \mathrm{mg} / \mathrm{l}$. Berdasarkan hasil pengamatan untuk kandungan oksigen secara keseluruhan mampu membantu bakteri nitrifikasi untuk mengoksidasi amonia. Sementara untuk pengamatan $\mathrm{pH}$ yang dilakukan pada penelitian dimana diperoleh nilai $\mathrm{pH}$ yang tidak terlalu jauh dalam fluktuasinya yaitu 6 7 pada perlakuan yang menggunakan gula aren sedangkan pada perlakuan kontrol berkisar $5-7$. Pada pengamatan fermentasi selama 15 - 20 hari perubahan $\mathrm{pH}$ terjadi pada saat 10 hari pertama dimana kondisi fermentasi menunjukkan nilai $\mathrm{pH}$ yang rendah dan bersifat asam serta bau yang menusuk sampai pada $>10$ nilai $\mathrm{pH}$ berubah ke arah normal dan hilang bau yang menusuk, hal tersebut terjadi karena proses penguraian mikroba memecah protein dan komponen nitrogen lainnya sehingga menghasilkan bau yang busuk.

Kandungan salinitas selama kegiatan penelitian di laporkan tidak mengalami fluktuasi yang jauh karena media dari tepat budidaya yang tidak melakukan proses perganitian air dan dilakukan indoor adapun nilainya berkisar sekitar 30 - 35 ppt. Menurut van wyk et all (1999), bahwa udang vaname dapat hidup pada kisaran salinitas yang lebar dari 0,5-35 ppt. Udang yang digunakan dalam penelitian menggunakan udang berukuran Post larva, pengaruh salinitas sangat berkaitan dengan kemampuan fisiologis udang untuk osmoregulasi yaitu kemampuan untuk menjaga keseimbangan garam dan air. Pada udang ketika kandungan salinitas tidak sesuai yang memberikan pengaruh yaitu pada organ filamen insang yang bersifat sebagai organ primer yang berfungsi mengatur keseimbangan garam. Peningkatan salinitas media akan meningkatkan osmolaritas hemolymph vannamei (Buckle et al, 2006).

Walaupun menurut Menurut Boyd (1998), kandungan nitrit yang dapat ditoleransi oleh udang vaname berkisar 0,1 - $1 \mathrm{mg} / \mathrm{L}$, tetapi nilai yang diperoleh selama pengamatan masih dapat ditoleransi ditoleransi oleh udang vaname karena tidak mengganggu pertumbuhan dan kelangsungan hidup udang vaname selama masa pemeliharaan. Nitrat akan bersifat toksik pada konsentrasi di atas 300 ppm (Masser et al., 1999), tetapi pada udang konsentrasi nitrat lebih dari 200 ppm akan memperngaruhi pertumbuhan serta daya tahan udang terhadap penyakit (Van Wyk dan Scarpa, 1999). Hasil yang diperoleh untuk hasik nitrat secara keseluruhan yang tertinggi hanya pada perlakuan kontrol yaitu 9,03 - 18,77 Mg/l, sementara untuk perlakuan yang menggunakan gula aren lebih rendah lagi 3,53-18,31 Mg/l.

Pada budidaya udang sistem konvensional untuk mengurangi kadar amonia dalam air dilakukan dengan melakukan pergantian air, sementara pada sistem bioflok dilakukan dengan penambahan bahan berkarbon. Penambahan berkarbon tersebut mampu mengurangi nitrogen anorganik dan menggantikan protein pakan (Avnimelech, 1999). Perlakuan penambahan sumber karbohidrat memberikan pengaruh yang lebih baik karena bakteri akan menggunakan gula aren yang kaya akan karbon dan nitrogen anorganik untuk sintesis protein mikrobial. Biosintesis protein mikroba berakibat pada terhambatnya proses pembentukan nitrogen anorganik sehingga akan mengurangi jumlah nitrogen anorganik dalam kolom air (Avnimelech, 1999). Burford et al., (2004) menyatakan vannamei terbukti dapat memanfaatkan dan mempertahankan nitrogen yang terdapat pada bioflok dan kemungkinan 29\% pakan harian berasal dari flok tersebut.

Pada hasil pengukuran yang diperolah dalam penelitian yaitu nilai range tertinggi ada perlakuan kontrol sekitar 85 - $295 \mathrm{Mg} / \mathrm{L}$ hal ini di indikasikan karena budidaya yang tidak memberlakukan sistem pergantian air dan tidak adanya perlakuan sehingga flokulasi tidak terbentuk. Sementara untuk perlakuan yang hanya menggunakan gula aren memiliki nilai konsentrasi TSS sekitar 95 -195 Mg/L kemudian yang terendah pada perlakuan yang menggunakan gula aren dan tepung ikan, pada perlakuan dengan penambahan sumber karbohidrat terjadi proses flokulasi sehingga endapan sebagian besar di ubah menjadi flok yang menjadi bahan makanan udang. Pada umumnya pada sistem budidaya konvensional yang dilakukan pada media dasar tanah di asumsikan bahwa nilai TSS yang tinggi merupakan bahan makanan juga untuk organisme budidaya, tetapi pada budidaya sistem bioflok kandungan flok yang diharapkan menggantikan peran pakan buatan dalam kegiatan budidaya karena selain meminimalisir pengolahan kualitas air flok juga berperan mengefisienkan pakan pada budidaya udang vaname. Secara keseluruhan parameter kualitas air selama penelitian masih dalam kisaran yang normal.

\section{Kesimpulan}

Budidaya udang vaname dengan sumber karohidrat gula aren secara keseluruhan memperbaiki beberapa parameter kualitas air, dengan adanya fermentasi gula aren yang menghasilkan bakteri 
asam laktat juga berperan produktifitas udang vaname.

\section{Daftar Pustaka}

iyushirota. 2009. Konsep Budidaya Udang Sistem Bakteri Heterotroph Dengan Bioflocs. Bandung. Biotechnology Consulting.

Avnimelech, Y. 1999. C/N Ratio As A Control Element In Aquaculture Systems. Aquaculture: 227-235.

Buckle, L., Baron F.B., dan Hernandez M. 2006. Osmoregulatory capacity of the shrimp Litopenaeus vannamei at different temperatures and salinities, an d optimal culture environment. Rev. Bioi. Trop. (Int. J Trop. Biol. ISSN-0034-7744), Vol. 54 (3):745753.

Burford, M.A., Thompson P.J., Mclntosh R.P., Bauman R.H. dan Pearson D.C. 2004. The Contribution of Flocculated Material to Shrimp (Litopenaeus vannamei) Nutrition in a High-intensity, Zero-exchange System. Aquaculture 232:525 537.

Boyd C.E., Tucker C.S. 1998. Pond aquaculture water quality management. 700 pp. Kluwer Academic Publishers. Norwell Massachusetts, USA.

Eliayani Y., Surahwardan H., dan Surjono. 2015. Pengaruh Pemberian Probiotik Bacillus sp. terhadap Profil Kualitas Air, Pertumbuhan dan Kelangsungan Hidup Benih Ikan Lele (Clarias gariepinus). Jurnal Penyuluhan Kelautan dan Perikanan Indonesia, 9 (1): 73 $-86$

Masser M. P., Rakocy J., dan Losordo T. M. 1999. Recirculating aquaculture tank production systems. Management of recirculating systems. SRAC Publication.

Stickney RR. 2005. Aquaculture: An Introductory Text. Oxford: CABI Publishing, 265

Subagiyo., Sebastian M., Triyono dan Willis A.S. 2015. Pengaruh pH, Suhu Dan Salinitas Terhadap Pertumbuhan dan Produksi Asam Organik Bakteri Asam Laktat Yang Diisolasi Dari Intestinum Udang Penaeid. IImu Kelautan Vol 20(4):187-194

Crab R., Bossier P., Avnimelech Y., Defoirdt T., and Verstraete W. 2007. Nitrogen Removal Techniques in Aquaculture for Sustainable Production. Aquaculture, 270: 1-14

Rachmawati D., Istiyanto S., dan Heryoso S. 2015. Manajemen Kualitas Air Media Budidaya Ikan Lele Sangkuriang (Clarias Gariepinus) Dengan Teknik Probiotik Pada Kolam Terpal Di Desa Vokasi Reksosari, Kecamatan Suruh, Kabupaten Semarang. PENA Akuatika 2 (1)

Van Wyk P., Megan D.H, Rolland L., Kevan L., Joe M., John S. 1999. Farming marine shrimp in
Recirculating Freshwater System. Harbor Branch Oceanographic Institution

Zulfahmi., I. 2017. Pengaruh Padat Tebar Berbeda Terhadap Pertumbuhan Benih Udang Windu (Penaeus Monodon Fabricius, 1798) Yang Dipelihara Pada Media Bioflok Scientiae Educatia: Jurnal Pendidikan Sains. Vol 6 (1): 62-66 